Studia Źródłoznawcze, t. LVI

p-ISSN 0081-7147

e-ISSN 2451-1331

Ewa KOBYLIŃSKA

Biblioteka Narodowa

\title{
O lekarzu królewskim Macieju z Błonia i jego zapiskach biograficzno-historycznych
}

Zarys treści: Artykuł poświęcony jest postaci lekarza królewskiego Macieja z Błonia, żyjącego na przełomie XV i XVI w., przede wszystkim na podstawie zachowanych zapisek biograficznych jego autorstwa, umieszczonych na wyklejce dzieł Awicenny przechowywanych w Bibliotece Prowincjalnej przy Wyższym Seminarium Duchownym Franciszkanów w Krakowie. Tekst zawiera również próbę określenia czynników, które mogły wpłynąć na jego karierę oraz stopnia jej typowości lub unikalności. Jest także próbą scharakteryzowania pozostawionych przez Macieja wpisów i przedstawienia ich na tle innych zapisów z epoki. W aneksie zamieszczono też edycję odnalezionych zapisek.

\begin{abstract}
The article presents the personage of royal physician Maciej of Błonie, who lived at the turn of the $16^{\text {th }}$ century, mainly on the basis of biographical notes written by him preserved in an endpaper of Avicenna's texts kept in the Provincial Library at the Higher Theological Seminary of Franciscans in Krakow. An attempt is also made to determine factors which could have influenced his career and a degree of its typicality or uniqueness. Next, the study seeks to characterise entries made by Maciej and present them in the context of other writings of his times; in addition, it contains an edition of his notes.
\end{abstract}

Słowa kluczowe: Maciej z Błonia, zapiski biograficzne, Aleksander Jagiellończyk, XVI w., lekarz

Keywords: Maciej of Błonie, biographical notes, Alexander Jagiellon, $16^{\text {th }}$ century, physician

Nie ulega wątpliwości, że mimo olbrzymich strat, jakie poniosły polskie zbiory na przestrzeni dziejów, źródła do historii późnego średniowiecza kryjące się w bibliotekach dalekie są od wyczerpania. Szczególnie ciekawe, a jednocześnie wyzyskane jeszcze w niewielkim stopniu, wydają się zapiski biograficzno-historyczne, które można odnaleźć w XV- i XVI-wiecznych drukach ${ }^{1}$ i rękopisach ${ }^{2}$. Bardzo często wpisy tego typu znajdują się w kalendarzach, almanachach i efemerydach. Zjawisko to zostało już częściowo omówione przez Rafała Wójcika w tekście Zapiski z efemeryd i almanachów XV i XVI wieku. Plan wydawniczy serii „Diariusze Staropolskie”, który jest także redaktorem wzmiankowanej serii ${ }^{4}$.

${ }^{1}$ A. Czekajewska-Jędrusik, Elementy rękopiśmienne w książce drukowanej, w: Książka rękopiśmienna XV-XVII w., red. B. Bieńkowska, Z Badań nad Polskimi Księgozbiorami Historycznymi, t. 4, Warszawa 1980, s. 85-86.

${ }^{2}$ Zapiski tego rodzaju nie traciły na popularności także w późniejszym okresie, występowały m.in. w szlacheckich księgach typu silva; zob. J. Partyka, Rękopisy dworu szlacheckiego doby staropolskiej, Warszawa 1995, s. 55, 76.

3 R. Wójcik, Zapiski z efemeryd i almanachów XV i XVI wieku. Plan wydawniczy serii „Diariusze Staropolskie”, w: Kalendarze staropolskie, red. I. Dacka-Górzyńska, J. Partyka, Warszawa 2013, s. 53-60.

${ }^{4}$ Do tej pory ukazały się: Jana Żdżarowskiego, kanonika poznańskiego, diariusz z lat 1532-1551, oprac. R. Wójcik, W. Wydra, Poznań 2009; Diariusze z XVI wieku w druku BJ Cim. 8421: Jan Musceniusz, Jan Krzysztoporski, Stanisław Krzysztoporski, oprac. J. Partyka, M. Malicki, Poznań 2009. 
Badacz ten zwrócił m.in. uwagę na przyczyny, dla których źródła tego typu były dotychczas wydawane i wykorzystywane $\mathrm{w}$ sposób marginalny. Z jednej strony kryją się one zazwyczaj w drukach obcych, podczas gdy priorytetowo wydawane są głównie katalogi poloników, stąd bibliotekarze będący kustoszami zbiorów nie mają świadomości ich istnienia ${ }^{5}$. Często również osoby zajmujące się katalogowaniem nie mają możliwości zamieszczania informacji charakteryzujących odnajdowane $\mathrm{w}$ drukach zapiski ${ }^{6}$. Ze względu na stan zaawansowania prac katalogowych wiedza na temat wpisów biograficznych znajdujących się w drukach ma niewielkie szanse na przeniknięcie do środowiska historyków, a o wydobyciu poszczególnych zapisek na światło dzienne decyduje najczęściej przypadek. Z drugiej strony informacje te były przeważnie przeznaczone dla samego zapisującego i ewentualnie jego rodziny, stąd brakuje w nich często wskazówek umożliwiających identyfikację osoby piszącego i postaci występujących w zapiskach. Sprawia to, że zadanie określenia autora wpisów jest żmudne, wymaga rozległych poszukiwań w literaturze przedmiotu i często kończy się niepowodzeniem ${ }^{7}$. Osobnym zagadnieniem są kwestie parametryzacji nauki, które zniechęcają badaczy do wydawania krótkich, lecz wymagających ogromnego wysiłku wpisów ${ }^{8}$ oraz brak odpowiednich kompetencji paleograficznych, które umożliwiałyby odczyt osobistych i nieraz pisanych pospiesznie not ${ }^{9}$.

Zapiski biograficzno-historyczne, spisane na przedniej wyklejce ${ }^{10}$, kryje w sobie przechowywany w Bibliotece Prowincjalnej przy Wyższym Seminarium Duchownym Franciszkanów w Krakowie inkunabuł o sygnaturze Inc.35.II, który zawiera Canon i De viribus cordis Awicenny. Książka została wydana w Wenecji w 1490 r., w formacie $4^{\circ}$ dla oficyny Octaviano Scoto ${ }^{11}$. Tekst tych zapisek stanowi aneks do niniejszego artykułu ${ }^{12}$. Szczęśliwie wydaje się, że z dużą dozą prawdopodobieństwa można wskazać autora tych wpisów, którym był Maciej z Błonia, lekarz królów Aleksandra Jagiellończyka i Zygmunta Starego. Przemawia za tym kilka argumentów. Po pierwsze, wskazują na to daty immatrykulacji na Uniwersytet Krakowski i uzyskania tytułu bakałarza wymienione we wpisach ${ }^{13}$. Po drugie, zapiski biograficzne mówią również o uzyskaniu przez piszącego tytułu doktora we Włoszech, co znajduje potwierdzenie w literaturze przedmiotu poświęconej wspomnianemu lekarzowi ${ }^{14}$. Po trzecie, wpisy niejednokrotnie, oprócz dat związanych z dziejami całego Królestwa Polskiego, odnoszą się do wydarzeń istotnych dla Mazowsza i miejscowości mazowieckich: panującej tam zarazy, śmierci książąt, konfliktu Konrada III z Janem Giżyckim, ustanowienia plebana w Kaskach w pow. sochaczewskim; autor wskazuje też, że na studia do Krakowa wyruszył z Warszawy. Po czwarte wreszcie, o profesji i wykształceniu medycznym osoby czyniącej wspomniane zapiski może świadczyć tekst dzieł Awicenny zawarty w inkunabule. W literaturze wskazywano już, że dla osoby nieposiadającej wykształcenia medycznego przedstawiał on niewielką wartość praktyczną ${ }^{15}$. Warto również podkreślić, że dzieło

\footnotetext{
${ }_{5}^{5}$ R. Wójcik, Zapiski z efemeryd i almanachów, s. 56.

${ }^{6}$ Jako wyjątek można podać Katalog druków XV i XVI wieku w zbiorach Biblioteki Uniwersyteckiej w Warszawie, t. 1-7, Warszawa 1994-2017, gdzie na końcu każdego tomu znajduje się m.in. indeks rzeczowy zapisek rękopiśmiennych.

${ }^{7}$ R. Wójcik, Zapiski z efemeryd i almanachów, s. 56-57.

8 Tamże, s. 59.

9 Kalendarze staropolskie [rec.: P. Tafiłowskiego, <ohistorii.blogspot.com/2014/01/kalendarze-staropolskie.html>; dostęp: 4.07.2017].

${ }^{10}$ Nie została ona jednak przyklejona do okładziny księgi. Karta ta mogła również pełnić funkcje ochronne.

${ }^{11}$ Incunabula quae in bibliothecis Poloniae asservantur, t. 1, cz. 1, wyd. M. Bohonos, E. Szandorowska, A. Kawecka-Gryczowa, Wratislaviae 1970, $\mathrm{nr} 714$, jest to jedyny egzemplarz tego wydania w Polsce, wersja zdigitalizowana: <polona.pl/ item/46955013/4/> [dostęp: 4.07.2017].

12 Zdecydowałam się skoncentrować w niniejszym tekście właśnie na wpisach biograficzno-historycznych i nie odnosić się do zapisek związanych z medycyną, które również zawarte są na wyklejce inkunabułu, gdyż ich rzetelne opracowanie przekracza moje kompetencje. Niewątpliwie jednak zasługują one na bliższe zbadanie i powinny znaleźć się w orbicie zainteresowań historyków medycyny, podobnie jak inne recepty i marginalia medyczne zapisane na kartach dawnych książek.

${ }_{13}$ Metryka Uniwersytetu Krakowskiego z lat 1400-1508, t. 1, wyd. A. Gąsiorowski i in., T. Jurek, I. Skierska, współpr. R. Grzesik, Kraków 2004, 88e/012, s. 468; Księga promocji Wydziału Sztuk Uniwersytetu Krakowskiego z XV wieku, wyd. A. Gąsiorowski, współpr. T. Jurek, I. Skierska, W. Swoboda, Kraków 2000, 90/40.

${ }_{14}$ M. Zwiercan, Maciej z Błonia, w: PSB, t. 19, Wrocław 1974, s. 13-14.

15 W. Szelińska, Biblioteki profesorów Uniwersytetu Krakowskiego w XV i początkach XVI wieku, Wrocław 1966, s. 163.
} 
to opatrzone jest licznymi notami marginalnymi ułatwiającymi orientację w materiale, które pisane są tą samą ręką co wpisy biograficzne.

Wskazawszy na osobę autora zapisek, należy prześledzić, w jakim stopniu uzupełniają one dotychczasową wiedzę na temat Macieja z Błonia, który doczekał się biogramu w Polskim słowniku biograficznym ${ }^{16}$. Maciej był synem Stanisława, pisał się z położonego na Mazowszu Błonia ${ }^{17}$. Pochodził z rodziny mieszczańskiej, a w 1507 r. przyjął prawo miejskie w Krakowie ${ }^{18}$. W biogramie wskazane zostały daty jego studiów na Uniwersytecie Krakowskim oraz starano się określić okres jego studiów we Włoszech, przedstawiono także posiadane przez niego beneficja kościelne i jego rolę jako lekarza królewskiego ${ }^{19}$. W relacji Miechowity Maciej z Błonia był obecny w Wilnie przy Aleksandrze Jagiellończyku w czasie ostatniej choroby, starał się także wspólnie z Janem Łaskim odwieść króla od kuracji zleconej przez znachora Balińskiego ${ }^{20}$. Maciej uzyskał w czasie swego życia liczne beneficja kościelne: w 1505 r. wszedł do kapituły gnieźnieńskiej (z kanonii zrezygnował w 1516), w 1507 r. został plebanem w Sieradzu, w 1510 r. proboszczem u św. Marii Magdaleny w Poznaniu, w 1512 r. kanonikiem poznańskim, w 1514 r. prepozytem pułtuskim i plebanem w Zatorze. Do 1515 r. był kanonikiem warszawskim i łowickim, w tym roku został też kanonikiem krakowskim, do 1516 r. był także altarystą św. Doroty na zamku krakowskim ${ }^{21}$. Warto nadmienić, że po powrocie z Włoch związany był z Wydziałem Lekarskim Uniwersytetu Krakowskiego ${ }^{22}$.

Jak widać z powyższego zestawienia, stosunkowo niewiele wiadomo o wczesnym okresie kariery Macieja z Błonia, dodatkowych danych na ten temat mogą jednak dostarczyć zawarte w dziełach Awicenny zapiski biograficzne. Pierwsza z nowych informacji to data urodzin - $1465 \mathrm{r}$. W następnym roku, opisanym przez autora jako rok wielkiej zarazy panującej na Mazowszu, urodzić miał się jego brat Jerzy. W 1471 r., a więc w wieku 6 lat, Maciej z Błonia miał zostać oddany do szkoły, a w 1481 r., czyli jako 16-latek, uzyskać święcenia akolity. W oktawie Wielkanocy 1488 r., w wieku 23 lat, miał wyruszyć z Warszawy na studia do Krakowa, gdzie immatrykulował się w semestrze letnim tego samego roku ${ }^{23}$. W 1490 r., co odnotowuje zarówno zapiska biograficzna, jak i Księga promocji Wydziału Sztuk Uniwersytetu Krakowskiego, uzyskał tytuł bakałarza ${ }^{24}$. Kolejne wskazane przez Macieja z Błonia daty i wydarzenia z jego życia były również dotychczas nieznane. Zapisał, że w czerwcu $1495 \mathrm{r}$. wyruszył do Niemiec cum pueris, a w 1497 r. odnotował śmierć towarzyszących mu dzieci. Nie do końca jasne jest, czy chodziło o potomstwo przyszłego lekarza królewskiego, co wydaje się prawdopodobne, biorąc pod uwagę odnotowanie tego wśród zapisek biograficznych, czy też o niezidentyfikowane bliżej dzieci, których był opiekunem, czy też o sługi medyka. Nie można więc wykluczyć, że po studiach Maciej z Błonia zawarł związek małżeński (wpisy biograficzne wskazują, że miał jedynie niższe święcenia, a wiadomość o pierwszym beneficjum kościelnym pochodzi dopiero z 1505) lub doczekał się potomka ze związku pozamałżeńskiego, chociaż przy obecnym stanie wiedzy o jego osobie nie sposób tego zweryfikować. Nie można także dzisiaj określić przyczyn i celu wyprawy do Niemiec. Jednocześnie warto dodać, że do 1496 r. miał być on rektorem szkoły Wszystkich Świętych w Krakowie ${ }^{25}$, a więc być może pobyt zagraniczny nie trwał długo i wiązał się w jakiś sposób z jego obowiązkami.

\footnotetext{
${ }^{16}$ M. Zwiercan, Maciej z Błonia.

${ }^{17}$ Warto nadmienić, że jest on, obok Mikołaja z Błonia, jedną z dwóch osób, którymi szczyci się ten ośrodek, a jego biogram został uwzględniony w popularnym opracowaniu dziejów miasta; M.W. Solarz, Błonie. Książęce miasto na Mazowszu, Kwidzyn 2010, s. 37-38.

${ }^{18}$ M. Zwiercan, Maciej z Błonia.

19 Tamże.

${ }^{20}$ Maciej z Miechowa, Chronica Polonorum, Cracoviae 1521, ks. IV, rozdz. 82.

${ }^{21}$ M. Zwiercan, Maciej z Btonia.

${ }_{22}$ M. Markowski, Pierwsi doktorzy medycyny Uniwersytetu Krakowskiego w świetle źródet rękopiśmiennych, „Przegląd Tomistyczny", 6/7, 1997, s. 326, 328, 330.

${ }^{23}$ Metryka Uniwersytetu Krakowskiego, 88e/012, s. 468.

${ }^{24}$ Księga promocji Wydziału Sztuk, 90/40.

${ }^{25}$ M. Zwiercan, Maciej z Błonia.
} 
Między 1495 a 1498 r. Maciej z pewnością powrócił do Krakowa, gdyż odnotowuje, że 25 X 1498 wyruszył stamtąd do Włoch w celu zdobycia tytułu doktora, z którym powrócił do Krakowa 1 VIII 1502. Pozwala to sprecyzować czas odbywania przez niego studiów włoskich, który dotąd pozostawał nieznany - autor jego biogramu w PSB stwierdzał, że do Włoch wyjechał on ok. 1499 r., do Krakowa powrócił przed marcem 1504 r., a tytuł doktora medycyny uzyskał zapewne w 1507 r. jako Mathias Polonus $^{26}$. Nadal nie udało się jednak stwierdzić, w którym z włoskich miast uzyskał stopień doktora, nie informują o tym zapiski, danych na ten temat nie dostarcza również dotychczasowa literatura przedmiotu poświęcona Polakom studiującym we Włoszech na przełomie średniowiecza i odrodzenia ${ }^{27}$.

Późniejsze daty wymienione we wpisach dotyczyły już wyłącznie wydarzeń politycznych: śmierci Fryderyka Jagiellończyka i Konrada III, mianowania Jana Łaskiego kanclerzem koronnym i śmierci Aleksandra Jagiellończyka. Wpis na temat zgonu króla jest też najpóźniejszy chronologicznie, chociaż wiadomo, że Maciej z Błonia zmarł dopiero w 1517 r. Być może jednak w późniejszym okresie utracił lub przestał korzystać z książki Awicenny, albo też śmierć Aleksandra Jagiellończyka była dla niego ważną cezurą.

Zapisy można generalnie podzielić na te dotyczące życia osobistego Macieja z Błonia oraz odnoszące się do Mazowsza i Korony, a także papiestwa.

$\mathrm{Na}$ wpisy dotyczące życia Macieja składają się: narodziny jego i brata, pójście do szkoły, przyjęcie święceń, wyjazd na studia, uzyskanie tytułu bakałarza, wyjazd do Niemiec, śmierć dzieci, wyjazd do Włoch i powrót do Krakowa z tytułem doktora. Co interesujące, nie zostało odnotowane uzyskanie żadnego z beneficjów kościelnych, mimo że kanonię gnieźnieńską Maciej objął przez prokuratora już w 1505 r. Przed kapitułą pojawił się jednak osobiście dopiero w 1509 r. i dopiero wtedy złożył też przysięgę ${ }^{28}$, co mogło być przyczyną niezamieszczenia wpisu o tym. Prawdopodobnie w tym okresie dla Macieja bardziej istotne były bieżące wydarzenia - objęcie funkcji lekarza królewskiego, towarzyszenie monarsze w wyprawie do Wilna i w jego ostatniej chorobie. Brak osobistych wpisów dotyczacych beneficjów kościelnych może świadczyć o tym, że zapiski biograficzno-historyczne powstały właśnie ok. 1506 r., a nie z perspektywy wielu lat.

Ciekawy wydaje się natomiast wybór wydarzeń niezwiązanych ściśle z osobistym życiem królewskiego medyka. Można je podzielić ze względu na zasięg ich oddziaływania, co przedstawia poniższa tabela.

\begin{tabular}{|l|l|}
\hline \multicolumn{1}{|c|}{ Tematyka zapiski } & \multicolumn{1}{|c|}{ Odnotowane wydarzenia } \\
\hline \multirow{3}{*}{ Mazowsze } & 1466 - zaraza na Mazowszu \\
\cline { 2 - 2 } & 10 II $1473-$ objęcie parafii w Kaskach ${ }^{29}$ przez plebana Aleksego \\
\cline { 2 - 2 } & 1488 - śmierć księcia Bolesława \\
\cline { 2 - 2 } & 1490 - zniszczenie przez Jana Giżyckiego Warki i wielu wsi należących do Konrada III \\
\cline { 2 - 2 } & 16 II 1495 - śmierć Janusza II \\
\cline { 2 - 2 } & 28 X 1503 - śmierć Konrada III \\
\hline
\end{tabular}

26 Tamże.

${ }^{27}$ Wśród przejrzanych pozycji powstałych po wydaniu biogramu Macieja w PSB, a dotyczących tego tematu można wymienić m.in.: M. Chachaj, Związki kulturalne Sieny i Polski do końca XVIII wieku. Staropolscy studenci i podróżnicy w Sienie, Sieneńczycy i ich dzieła w Polsce, Lublin 1998; T. Ulewicz, Iter romano-italicum polonorum czyli o zwiazkach umystowo-kulturalnych Polski z Włochami w wiekach średnich i renesansie, Kraków 1999; S.A. Sroka, Wykaz Polaków wypromowanych na Uniwersytecie w Bolonii w drugiej połowie XV w., Kwart. Hist., 121, 2014, nr 1, s. 133-155; D. Quirini-Popławska, Italia mia. Studia z dziejów Italii i stosunków polsko-włoskich w późnym Średniowieczu i Renesansie, Kraków 2016. T. Brzeziński w pracy Polskie peregrynacje po dyplomy lekarskie (od średniowiecza po odzyskanie niepodległości w 1918 r.), Warszawa 1999, umieścił Macieja wśród absolwentów Uniwersytetu w Bolonii jako Mateusza Polaka, powołując się jednak jedynie na ustalenia wcześniejszej literatury (tamże, s. 168).

28 J. Korytkowski, Prałaci i kanonicy katedry metropolitarnej gnieźnieńskiej od roku 1000 aż do dni naszych podtug źródeł archiwalnych, t. 1, Gniezno 1883, s. 47.

${ }^{29}$ Kaski w pow. sochaczewskim; zob. Kaski. Kartoteka powiatu sochaczewskiego w średniowieczu. Kartoteka Stownika historyczno-geograficznego Mazowsza $w$ średniowieczu, $<$ rcin.org.pl/dlibra/docmetadata?id=55103\&from=\&dirids=1\&ver_id=\&1$\mathrm{p}=1 \& \mathrm{QI}=>$ [dostęp: 8.05.2018]. Miejscowość ta była oddalona od Błonia o ok. $15 \mathrm{~km}$. 


\begin{tabular}{|l|l|}
\hline \multirow{5}{*}{ Korona } & wrzesień 1474 - wojna na Śląsku \\
\cline { 2 - 2 } & 17 VI 1501 - śmierć Jana Olbrachta \\
\cline { 2 - 2 } & 29 X 1501 - koronacja króla Aleksandra \\
\cline { 2 - 2 } & marzec 1503 - śmierć Fryderyka Jagiellończyka \\
\cline { 2 - 2 } & 24 X 1503 - Jan Łaski zostaje kanclerzem \\
\cline { 2 - 2 } & 19 VIII 1506 - śmierć Aleksandra Jagiellończyka \\
\hline Kościół powszechny & 27 VIII [1492] - koronacja papieża Aleksandra VI \\
\hline
\end{tabular}

Wśród wymienionych wydarzeń jedno zwraca szczególną uwagę, ze względu na jego lokalny charakter - ustanowienie proboszcza Aleksego w parafii w Kaskach ${ }^{30}$. Z jednej strony można chyba przypuszczać, że osoba duchownego odegrała szczególną rolę w życiu Macieja, z drugiej jednak miał on chyba problem z przypomnieniem sobie jego imienia, gdyż zostało ono nadpisane nad przekreśleniem ${ }^{31}$.

Ciekawy wydaje się również sposób przedstawienia kwestii złupienia Warki i innych wsi należących do księcia Konrada III przez Jana Giżyckiego. W rzeczywistości w podanym przez Macieja z Błonia roku Jan Giżycki, tenutariusz w Wielkiej Woli, popadł w konflikt z księciem Konradem III, który został zakończony wyrokiem królewicza Jana Olbrachta. Zasądził on, że książę ma zapłacić Giżyckiemu 2000 florenów oraz zwrócić zapisy na Giżyce i Roszki w zamian za zapis na Wielkiej Woli ${ }^{32}$. Sam przebieg tego konfliktu i działania Giżyckiego nie zostały odnotowane ani przez opracowania dotyczące Warki ${ }^{33}$, ani przez Kartotekę Słownika historyczno-geograficznego Mazowsza w średniowieczu ${ }^{34}$. Trudno powiedzieć, czy Maciej był w tym czasie na Mazowszu, ale wydarzenie to było prawdopodobnie szeroko komentowane, mogło też dotknąć bliskich mu osób lub miejscowości, skoro zostało uwzględnione na wyklejce inkunabułu. Warto nadmienić, że konflikt ten był dla Mazowsza wydarzeniem bezprecedensowym, sprzecznym bowiem z lokalną tradycją współpracy między możnymi a władzą książęcą ${ }^{35}$, a miejscowości, z którymi związany był Giżycki, czyli Wielka Wola, Giżyce i Roszki, znajdowały się w odległości ok. 20-40 km od Błonia, a więc można je uznać za znajdujące się $\mathrm{w}$ rodzinnych stronach medyka.

Warte podkreślenia wydaje się, że wydarzenia związane z Mazowszem dotyczyły także okresu, gdy Maciej przebywał poza tą dzielnicą. Można przypuszczać, że to, co działo się w księstwie nadal go interesowało. Pytaniem otwartym pozostaje, czy książęta mazowieccy wymienieni we wpisach odgrywali jaką́s rolę w rozwoju jego kariery.

Bardzo interesujące wydają się również zapisy dotyczące Korony, gdyż zasadniczo obejmują one przede wszystkim panowanie Aleksandra Jagiellończyka, nie licząc wpisu informującego o wojnie na Śląsku w 1474 r., która przywołana jest aż dwukrotnie. Po raz pierwszy ma to miejsce na k. Ir, gdzie jest to jedyna zapiska o charakterze historycznym, umieszczona pomiędzy notami dotyczącymi medycyny $^{36}$. Po raz drugi wydarzenie to przywołane jest chyba na karcie Iv, tam jednak zapis jest uszkodzony i zachował brzmienie: ,ad Slesiam fuit circa festum Michaelis 1474”. Ten drugi zapis wyróżnia się kolorem atramentu, którym odbiega od pozostałych wpisów, nie sposób jednak stwierdzić, czy było to działanie zamierzone. Trudno wyjaśnić, czemu ważne dla autora były wydarzenia na Śląsku, wymienione jako jedyne odnoszące się do panowania Kazimierza Jagiellończyka, nie można wykluczyć, że ktoś z rodziny bądź bliskich znajomych Macieja brał udział w tej wyprawie.

30 Zob. tamże.

31 Wydaje się, że pierwotnie wpisano imię Szymon.

32 Słownik historyczno-geograficzny ziemi warszawskiej w średniowieczu, oprac. A. Wolff, K. Pacuski, do dr. przyg. M. Piber-Zbieranowska, A. Salina, red. T. Jurek, Warszawa 2013, s. 309.

33 Np. Dzieje Warki 1321-1971. studia i materiaty, red. B. Dymek i in., Warszawa 1975; Stara Warka: wieś z dtuga historia, Stara Warka 2012.

34 Hasło: Stara Warka, <rcin.org.pl/dlibra/docmetadata?id=29664\&from=\&dirids=1\&ver_id=\&lp=1\&QI=> [dostęp: 17.08.2017].

35 K. Pacuski, Możnowładztwo i rycerstwo ziemi gostynińskiej w XIV i XV wieku. Studium z dziejów osadnictwa i elity władzy na Mazowszu średniowiecznym, Warszawa 2009, s. 99.

36 Karta jest bardzo nieczytelna ze względu na pełnione funkcje ochronne i charakter zapisek, stąd wątpliwość, czy pomiędzy notami nie ukrył się jeszcze jakiś wpis biograficzno-historyczny. 
Kolejną chronologicznie odnotowaną datą jest śmierć Jana Olbrachta, a ostatnią - zgon Aleksandra Jagiellończyka. Wydaje się to wskazywać, że dla piszącego okres ten był niezwykle ważny, co nie dziwi, biorąc pod uwagę sprawowaną przez niego funkcję lekarza królewskiego. W tym kontekście zwraca także uwagę zapiska mówiąca o śmierci króla: „Item rex Allexander die 19 Augusti hora noctis tertia mortuus est 1506", tak dokładny opis, zgodny zresztą z innymi przekazami określającymi moment śmierci króla na czas pomiędzy godziną 3 a $4 \mathrm{w}$ nocy ${ }^{37}$, wiąże się z pewnością z faktem obecności Macieja przy umierającym władcy.

Wydaje się, że podanie wśród wpisów informacji o mianowaniu Jana Łaskiego kanclerzem może być symptomatyczne. Przyszły arcybiskup odegrał najpewniej szczególną rolę w karierze Macieja z Błonia.

Charakterystyczny wydaje się brak wśród wpisów odnotowania zarówno śmierci Kazimierza Jagiellończyka, jak i objęcia tronu przez Jana Olbrachta, chociaż znajdują się tam niemal współczesne wpisy dotyczące wydarzeń politycznych na Mazowszu. Świadczy to zapewne o tym, że udział Macieja z Błonia w służbie Koronie i zainteresowanie nią były ściśle związane z panowaniem i osobą Aleksandra Jagiellończyka. Teoretycznie niewykluczone jest, że wyrażone we wpisach podsumowanie życia królewskiego lekarza nastąpiło wkrótce po śmierci króla i wynikało z przeżyć związanych z tym wydarzeniem. Jednak chociaż wyjaśniałoby to fakt, że była to najpóźniejsza chronologicznie zapiska, to rozwiązanie takie jest jedynie jedną z możliwych hipotez.

Na tym tle zdecydowanie wyróżnia się zapis dotyczący papieża Aleksandra VI, jako jedyny odnoszący się do papiestwa. Trudno powiedzieć, co wpłynęło na wybór takiego, a nie innego wydarzenia z historii powszechnej, Maciej nie odnotował m.in. śmierci Kazimierza Jagiellończyka w tym samym roku ani wyboru następcy Aleksandra VI w 1503 r. Ciekawe jest również to, że zapiska ta, jako jedyna, znajduje się na oddzielnej stronie, co sprawia wrażenie, jakby wpisy miały być kontynuowane. Być może na zamieszczenie informacji wpłynął fakt, że Maciej z Błonia mógł widzieć papieża podczas swojego pobytu we Włoszech. Można też chyba przypuszczać, że będąc we Włoszech w roku jubileuszowym 1500, skorzystał z okazji, aby pojechać do Rzymu ${ }^{38}$. Data koronacji papieża Aleksandra VI ${ }^{39}$ odnotowana została również w pamiętniku świadka tych wydarzeń - Ambrożego Pampowskiego ${ }^{40}$, dyplomaty w służbie Jana Olbrachta i Aleksandra oraz starosty generalnego Wielkopolski ${ }^{41}$, a Pampowski i Maciej z Błonia mogli utrzymywać jakieś kontakty, chociażby ze względu na ich działalność przy królu. Warto też nadmienić, że Pampowski w swoim pamiętniku wynotował również kilka recept medycznych autorstwa Macieja ${ }^{42}$.

Także noty marginalne znajdujące się w należącym do Macieja z Błonia wydaniu dzieł Awicenny mogą zawierać pewne dodatkowe informacje o zainteresowaniach ich autora. Bez wątpienia zasługują one na bliższe zbadanie przez historyka medycyny, jednak już w tym miejscu warto zaznaczyć, że chociaż liczne, to nie są rozłożone równomiernie w całym dziele. Przede wszystkim obejmują całą księgę pierwszą oraz pierwszy traktat księgi drugiej, które dotyczą głównie teorii medycyny i powszechnych leków. Dalsza część dzieła opatrywana była notami jedynie sporadycznie, wiele kolejnych kart nie zawiera żadnych uwag czytającego lub występują na nich jedynie pojedyncze wpisy ${ }^{43}$. Może to świadczyć o tym, że Maciej z Błonia więcej uwagi poświęcił tej części dzieła, która dotyczyła teorii medycyny, kosmologii i ludzkiego ciała, a mniej zagadnieniom związanym z lekami czy poszczególnymi

37 Miechowita określał godzinę śmierci króla na 4 (zob. M. Starzyński, Ultima voluntas Alexandri Regis, w: Ecclesia, regnum, fontes. Studia z dziejów średniowiecza, red. S. Gawlas i in., Warszawa 2014, s. 262), taką samą informację początkowo otrzymał Erazm Ciołek, później powiadomiono go, że miało to jednak miejsce o 1 (zob. L.A. Birkenmajer, Zapiski historyczne wśród starych almanachów Biblioteki Jagiellońskiej, Kwart. Hist., 16, 1902, s. 454-455).

${ }^{38} \mathrm{O}$ wyjazdach Polaków do Rzymu na rok jubileuszowy zob. H. Barycz, Polacy na studiach w Rzymie w epoce odrodzenia (1440-1600), Kraków 1938, s. 70-73.

39 Różniła się ona jednak o jeden dzień od tej podanej przez Macieja z Błonia.

40 J. Wiesiołowski, Pamiętnik starosty Pampowskiego, „Kronika Miasta Poznania”, 4, 2004, s. 123.

41 Biogram Ambrożego Pampowskiego zob. tenże, Pampowski Ambroży, w: PSB, t. 25, Wrocław 1980, s. $105-107$.

${ }^{42}$ Są tam też wymienione recepty innych lekarzy tego czasu; BCzart., sygn. 190 II Inc., k. 169-170v. Za udostępnienie mikrofilmu tego inkunabułu do BN dziękuję pracownikom BCzart. oraz Zakładu Wypożyczania Krajowego i Zagranicznego BN.

${ }^{43}$ Not brakuje niemal zupełnie np. na k. 68-132v, 217-310v, 324-386. 
chorobami. Przyczyn takiego zjawiska można upatrywać zarówno w stopniowym zmęczeniu lekturą i notatkami, jak i w tym, że Maciej mógł posiadać praktyczne doświadczenie w dziedzinie chorób i lekarstw, przez co nie czuł potrzeby opatrywania tej części dzieła liczniejszymi uwagami.

Niejako na marginesie rozważań dotyczących wpisów biograficznych Macieja z Błonia warto chyba spróbować prześledzić kontakty osobiste, które mogły mieć wpływ na kształtowanie się kariery lekarza, ale także dają pewną szansę na określenie stopnia typowości lub wyjątkowości jego zapisek wśród diariuszy przełomu XV i XVI w.

Mimo wielokrotnego pojawiania się w zapiskach biograficzno-historycznych wydarzeń związanych z książętami mazowieckimi, nie udało się odnaleźć śladów bezpośrednich powiązań Macieja z dworem książęcym. Wpisy wydają się mieć charakter świadczący jedynie o zainteresowaniu miejscem pochodzenia, chociaż nie można wykluczyć, że łączyły go jednak jakieś związki z książętami Mazowsza.

Ciekawe natomiast wydaje się zestawienie osób, które w podobnym czasie studiowały na Uniwersytecie Krakowskim, gdyż wiele spośród nich weszło później do służby królewskiej. Oczywiście, liczba studentów na krakowskiej wszechnicy była znaczna, stąd nie ma pewności, że wspólnie odbywane studia oznaczały zawarcie znajomości. Prawdopodobieństwo takie jest wyższe w wypadku osób, które w podobnym czasie uzyskiwały tytuł bakałarza czy magistra. Niemniej nagromadzenie wśród studentów późniejszych dworzan królewskich wydaje się symptomatyczne. Można wśród nich wymienić m.in. Mikołaja z Wilkanowa, sekretarza królewskiego, archidiakona płockiego i administratora diecezji płockiej w czasie nieobecności Erazma Ciołka ${ }^{44}$, który studia rozpoczął w $1486^{45}$, bakałarzem został w $1488^{46}$, a magistrem w 1490 r. ${ }^{47}$, Andrzeja z Rostkowa, przyszłego lekarza Zygmunta I ${ }^{48}$, który na studia zapisał się w 1487 r. ${ }^{49}$, czy Wojciecha z Szamotul, lekarza królowej Elżbiety ${ }^{50}$, który w 1488 r. uzyskał tytuł magistra ${ }^{51}$. Nie sposób pominąć milczeniem faktu, że w tym czasie w Krakowie studiowali także przyszli biskupi: Piotr Tomicki, który bakalaureat uzyskał w tym samym roku co Maciej z Błonia ${ }^{52}$, i Erazm Ciołek, który rok później został magistrem ${ }^{53}$.

Inną okazją do zawierania lub pogłębiania korzystnych znajomości mógł być dla Macieja pobyt we Włoszech, zwłaszcza że - jak już wspomniano - przebywał on tam także podczas roku jubileuszowego. Wystarczy nadmienić, że w tym czasie do Italii zawitali również m.in. Andrzej Łaski, brat przyszłego prymasa, Stanisław Borek, który zresztą na studia na Uniwersytecie Krakowskim zapisał się w tym samym roku co Maciej ${ }^{54}$, Maciej z Miechowa, Mikołaj Kopernik, Stanisław Biel i Piotr Tomicki ${ }^{55}$. Dodajmy, że ten ostatni studiował w Bolonii ${ }^{56}$, gdzie być może wiedzę medyczną zgłębiał też Maciej z Błonia ${ }^{57}$.

Istotną osobą w życiu Macieja z Błonia był z pewnością Jan Łaski. Świadczy o tym nie tylko wpis o mianowaniu go kanclerzem koronnym, ale także wydarzenia, których nie wymieniają zapiski biograficzne. Wspólnie znaleźli się oni przy umierającym Aleksandrze Jagiellończyku i to na prośbę Macieja Łaski miał aresztować znachora Balińskiego. To właśnie Maciej był przedstawicielem kapituły gnieźnieńskiej przy konsekracji arcybiskupa oraz zajął kanonię poznańską po śmierci brata prymasa ${ }^{58}$. Maciej był także zarówno lekarzem, jak i wierzycielem Jana Łaskiego ${ }^{59}$.

44 J. Skibniewska, Dwór królewski Aleksandra Jagiellończyka w latach 1501-1506, Lublin 2015, s. 296.

${ }^{45}$ Metryka Uniwersytetu Krakowskiego, 86e/084.

${ }^{46}$ Księga promocji Wydziału Sztuk, 88/25.

${ }_{47}$ Tamże, 90/2.

${ }^{48}$ W. Pociecha, Królowa Bona (1494-1557): czasy i ludzie Odrodzenia, t. 2, Poznań 1950, s. 37.

${ }^{49}$ Metryka Uniwersytetu Krakowskiego, 87e/064.

${ }^{50}$ J. Skibniewska, Dwór królewski, s. 90.

${ }^{51}$ Księga promocji Wydziału Sztuk, 88/8.

52 Tamże, 90/75.

53 Tamże, 91/8.

${ }_{54}$ Metryka Uniwersytetu Krakowskiego, 88h/175.

${ }_{55}$ H. Barycz, Polacy na studiach w Rzymie, s. 70-73.

56 Tamże, s. 72.

57 J. Skibniewska, Dwór królewski, s. 213.

58 J. Korytkowski, Prałaci i kanonicy, s. 47.

59 P. Tafiłowski, Jan Laski (1456-1531), kanclerz koronny i prymas Polski, Warszawa 2007, s. 138, 290. 
Ciekawe wydają się również informacje na temat innych lekarzy działających na dworze królewskim Aleksandra Jagiellończyka. Józefa Skibniewska stwierdza, że wszyscy trzej medycy królewscy - Jan z Reguł, Adam z Bochyni (z Łowicza) oraz Maciej z Błonia - pochodzili z Mazowsza ${ }^{60}$. Adam z Łowicza i Maciej z Błonia należeli do jednego pokolenia, Adam studia rozpoczął dwa lata przed Maciejem, bakalaureat uzyskał w 1488, magisterium w 1492 r., a w końcu XV w. wyjechał za granicę, być może do Włoch, gdzie się doktoryzował ${ }^{61}$. Obaj pochodzili też zapewne z rodzin mieszczańskich ${ }^{62}$. O pokolenie starszy był natomiast Jan z Reguł. Pochodził on ze średniozamożnej mazowieckiej rodziny szlacheckiej, studia na Uniwersytecie Krakowskim rozpoczął w 1460 r. i po uzyskaniu stopnia magistra w 1468 r., kontynuował je we Włoszech, gdzie przed 1475 r. został doktorem medycyny ${ }^{63}$. Warto podkreślić, że przez blisko 40 lat był profesorem medycyny na Uniwersytecie Krakowskim, a także dziekanem Wydziału Medycyny oraz rektorem ${ }^{64}$, co mogło dać mu okazję do zapoznania się z przyszłymi lekarzami króla Aleksandra. Sam Jan był co najmniej od 1476 r. jednym z lekarzy Kazimierza Jagiellończyka, a później tę samą funkcję pełnił przy królach Aleksandrze i Zygmuncie ${ }^{65}$. W 1495 r. otrzymał także nadanie od księcia Konrada III, którego miał być nadwornym lekarzem ${ }^{66}$. Chociaż J. Skibniewska w swojej monografii dworu Aleksandra Jagiellończyka stwierdza, że wszyscy lekarze króla, mimo że pochodzili z Mazowsza, poprzez swoją działalność związani byli z Krakowem i Małopolską ${ }^{67}$, to takie nagromadzenie Mazowszan wśród lekarzy królewskich nie wydaje mi się zupełnie przypadkowe. W moim przekonaniu pewną rolę w takim doborze medyków odegrały powiązania osobiste. Nie można przykładowo wykluczyć, że Jan z Reguł wziął pod swoją opiekę dwóch studentów, którzy wykazywali inklinacje w kierunku zagłębiania nauk medycznych, interesujące jest również podobieństwo karier obu tych studentów. O tym, że lekarze królewscy nie stracili zupełnie kontaktu z dzielnicą pochodzenia świadczy z jednej strony podjęta przez Jana z Reguł funkcja lekarza nadwornego Konrada III, a z drugiej zapiski zamieszczone przez Macieja z Błonia w dziełach Awicenny.

Zastanawiająca wydaje się zbieżność między losami dwóch mazowieckich lekarzy królewskich mieszczańskiego pochodzenia - Macieja z Błonia i Adama z Łowicza. Chociaż kariera pierwszego z nich wydaje się nie odbiegać znacząco od tej, jaka była udziałem innych przedstawicieli jego pokolenia, to należy on do tych nielicznych przypadków, kiedy dzięki autorskim zapiskom biograficznym dysponujemy dokładnymi informacjami chronologicznymi ukazującymi jej początki. Pytaniem otwartym pozostaje, czy można na tej podstawie uznać, że wiek, w jakim Maciej z Błonia podejmował kolejne etapy edukacji czy uzyskał święcenia był charakterystyczny także dla innych jego rówieśników.

$\mathrm{Na}$ koniec warto dokładniej przyjrzeć się charakterowi poczynionych wpisów. Przede wszystkim zwraca uwagę fakt, że księga, na której kartach zostały one umieszczone, sprawia wrażenie dosyć przypadkowej. Nie wydaje się, aby dzieła Awicenny, w przeciwieństwie chociażby do kalendarzy, w szczególny sposób inspirowały do życiowych rekapitulacji. Druga kwestia, która wydaje się istotna z punktu widzenia charakteru zapisów, to fakt, że nie są one ułożone w kolejności chronologicznej, a część z nich się powtarza, w tym także na desce przedniej okładziny ${ }^{68}$, można napotkać wśród nich również przekreślenia. Wszystko to sprawia, że zapisy wydają się mieć charakter roboczy czy szczególnie osobisty. Odnosi się wrażenie, że ich autorowi w mniejszym stopniu zależało na upamiętnieniu pewnych wydarzeń, a raczej na uporządkowaniu własnych wspomnień i określeniu tych, które były szczególnie istotne z jego punktu widzenia. Ciekawe wydaje się połączenie niektórych dat z życia Macieja i jego rodziny ze zdarzeniami o charakterze bardziej ogólnymi, np. narodzin brata z zarazą

${ }^{60}$ J. Skibniewska, Dwór królewski, s. 197-198. Do zestawienia nie wlicza ona Żyda Stefana Falko, wymienionego w innym miejscu; tamże, s. 88 .

${ }^{61}$ H. Barycz, Adam z Bochynia, PSB, t. 1, Wrocław 1935, s. 20.

62 Tamże.

${ }^{63}$ M. Markowski, Jan z Regut, w: PSB, t. 10, Wrocław 1964, s. 472.

${ }^{64}$ Tamże, s. 472-473.

65 Tamże, s. 473.

${ }^{66}$ Stownik historyczno-geograficzny ziemi warszawskiej w średniowieczu, s. 239.

${ }^{67}$ J. Skibniewska, Dwór królewski, s. 198.

${ }^{68} \mathrm{Na}$ desce przedniej okładziny widoczne są ślady wpisów biograficznych, które powtarzają się później na wyklejce. 
panującą na Mazowszu, wyjazdu na studia ze śmiercią księcia Bolesława i uzyskania tytułu bakałarza z konfliktem między księciem Konradem a Janem Giżyckim. Takie połączenia, oprócz prostego wytłumaczenia chęci uniknięcia powtarzania tej samej daty rocznej, mogły być zabiegiem ułatwiającym ustalenie i zapamiętanie chronologii wydarzeń. Wszystko to sprawia, że trudno oprzeć się wrażeniu, iż zapiski miały charakter roboczy, stanowiły raczej raptularz czy spominki niż szeroko rozpowszechniony w tym okresie diariusz ${ }^{69}$. Mogły one jednak stać się podstawą do bardziej rozwiniętych form pamiętnikarskich.

Daty dzienne poszczególnych wydarzeń podawane są stosunkowo rzadko, wydaje się, że nieco częściej w przypadku dat późniejszych chronologicznie. Często czas poszczególnych wydarzeń obrazowany jest z odwołaniem do świąt kościelnych. Może to nieco dziwić w przypadku lekarza, któremu nieobca była wiedza astrologiczna oraz wydaje się wyróżniające na tle innych diariuszowych zapisów z epoki, chociaż ich nowożytna datacja była zapewne wielokrotnie pochodną robienia notatek w kalendarzach. Szczególnie intrygujący jest sposób podania daty wyjazdu na studia do Włoch, gdyż Maciej odniósł się tam do dwóch świąt kościelnych, ale także wskazał datę dzienną na sposób nowożytny z podaniem godziny. Problem polega na tym, że każde z tych określeń wskazuje inny dzień: 25, 26 i 27 października. Także wyznaczenie daty śmierci księcia Janusza II poprzez odniesienie do wspomnienia św. Julianny wydaje się dziwne - autor pisze, że książę zmarł w poniedziałek po św. Juliannie, gdy tymczasem w 1495 r. święto to przypadało właśnie w poniedziałek i uznawane jest za faktyczną datę śmierci Janusza II. Wydaje się zatem, że chociaż Maciej często w swoich zapiskach posługuje się kalendarzem kościelnym, to jednak popełnia przy tym pomyłki.

Nie można także pominąć kwestii związanych z prawidłowością zamieszczonych przez medyka dat. W większości przypadków są one zgodne z dzisiejszą wiedzą na temat chronologii wydarzeń tamtego okresu, w sposób oczywiście błędny określona jest jedynie data koronacji Aleksandra Jagiellończyka. Autor podaje, że miało to miejsce 29 X 1501, podczas gdy faktycznie odbyła się ona 12 grudnia tr. Warto zauważyć jednak, że w tym czasie Maciej z Błonia przebywał na studiach w Italii, nie mógł więc być świadkiem wydarzeń w kraju, ale notując zapiski biograficzno-historyczne z perspektywy czasu i będąc lekarzem królewskim, z pewnością miał okazję zweryfikować swoje informacje. Taka pomyłka podkreśla jeszcze bardziej roboczy charakter wpisów, lekarz nie pokusił się na tym etapie o sięgniecie do innych źródeł niż własna pamięć. Należy jednocześnie podkreślić, że data śmierci Jana Olbrachta została przez niego podana prawidłowo, mimo że w tym czasie także znajdował się we Włoszech. Warto zauważyć, że od 1501 r. w Rzymie przebywała polska delegacja, której członkowie dysponowali informacjami z kraju i nie można wykluczyć, że byli źródłem wiedzy Macieja. Wiadomo, że w lipcu wieść o śmierci Jana Olbrachta, której datę lekarz królewski podał prawidłowo, dotarła do Erazma Ciołka. Opuścił on jednak Wieczne Miasto 11 grudnia, a więc w przeddzień koronacji Aleksandra, nie mógłby więc dostarczyć Maciejowi informacji o tym wydarzeniu, co mogło skutkować pomyłką medyka, pozbawionego rzetelnego źródła wieści z Polski ${ }^{70}$.

Maciej z Błonia jest jedną z wielu osób, które studiowały w latach 80. XV w. na Uniwersytecie Krakowskim, a później związane były z dworem królewskim. Część z nich mogła pozostawić po sobie rozmaite wpisy biograficzne i informacje rocznikarskie na marginesach książek drukowanych, tak było w przypadku chyba najwybitniejszego przedstawiciela tej grupy - Erazma Ciołka ${ }^{71}$. Zwyczaj ten nie był też obcy uczonym uniwersyteckim przełomu stulecia, w tym zwłaszcza lekarzom ${ }^{72}$, którym kul-

${ }^{69} \mathrm{Na}$ temat różnic między tymi pojęciami zob. R. Wójcik, Autobiographical Marginal Notes in Early Printed Calendars, Almanacs and Ephemerides as the Form of the Pre-memoirs in Poland in the $15^{\text {th }}$ and the $15^{\text {th }}$ centuries, w: ¿Que implica ser medievalista? Prácticas y reflexiones en torno al oficio del historiador, t. 3, red. A.V. Neyra, G. Rodríguez, Mar del Plata 2012, s. 163-168, <repozytorium.amu.edu.pl/bitstream/10593/6000/1/Diaries_Rafa\%C5\%82\%20W\%C3\%B3jcik.pdf> [dostęp: 29.08.2017].

${ }^{70}$ L.A. Birkenmajer, Zapiski historyczne (1902), s. 448-449.

${ }^{71}$ Tamże, s. 445-457.

72 Także późniejsi lekarze pozostawiali po sobie diariusze, zachował się m.in. tekst tego typu autorstwa Kaspra Goskiego, lekarza i burmistrza poznańskiego; zob. J. Wiesiołowski, Diariusz studencki burmistrza Goskiego, „Kronika Miasta Poznania”, 1, 1999, s. 67-77. 
tura książki była szczególnie bliska ${ }^{73}$, a w których kręgu obracał się przecież Maciej z Błonia. Jednym z najsłynniejszych przedstawicieli polskiego środowiska medycznego wykazującym zainteresowania historyczne był niewątpliwie Maciej z Miechowa ${ }^{74}$. Spisał on ok. 1508 r. na pustej karcie jednego z rękopisów uniwersyteckich ciąg zapisów rocznikarskich dotyczących dziejów Polski, Małopolski i Krakowa, które zostały wydane i opatrzone przez Henryka Barycza nazwą Rocznik Uniwersytecki ${ }^{75}$. Co ciekawe, zapiski te, chociaż koncentrujące się wyłącznie na wydarzeniach politycznych, wykazują pewne podobieństwa z tymi pozostawionymi przez Macieja z Błonia - spisane były w podobnym czasie, nie zachowują kolejności chronologicznej, zawierają również pewne niekonsekwencje w sposobie datowania (autor raz zapisał rok cyframi rzymskimi, w pozostałych przypadkach stosował cyfry arabskie) ${ }^{76}$.

Tematyka zapisek diariuszowych profesorów uniwersyteckich pozostaje jednak nadal nierozpoznana, mimo że ich znaczenie podkreślane było już co najmniej od lat 30 . XX w. ${ }^{77}$ Przykładowo można stwierdzić, że zapiski tego typu pozostawili po sobie Marcin Biem z Olkusza, jak również wywodzący się z Mazowsza Łukasz Noskowski, lekarz krakowski, którego teściem był notabene Jan z Reguł i który w swoim diariuszu odnotował dzień śmierci Macieja z Błonia ${ }^{78}$.

Wydaje się, że poczynione w czasie studiów znajomości mogły odegrać znaczącą rolę w późniejszych karierach wielu osobistości przełomu XV i XVI w., ale także kształtować wspólnotę zwyczajów i upodobań. Do tych ostatnich zaliczyć można także skłonność do prowadzenia notatek o charakterze biograficzno-historycznym. Można uznać, że zapiski pozostawione przez Macieja z Błonia są typowe dla środowiska dworskiego i uniwersyteckiego przełomu epok.

Reasumując, zapiski poczynione przez królewskiego medyka przynoszą liczne uściślenia dotyczące jego życia do 1506 r. Jednocześnie pozwalają stwierdzić, że w tym czasie ciągle istotne były dla niego wydarzenia na Mazowszu, a swoją działalność w Koronie związał bardzo silnie z osobą króla Aleksandra. Czy później stosunek ten uległ zmianie, wraz z uzyskiwaniem za wstawiennictwem królewskim kolejnych beneficjów kościelnych lub przyjęciem prawa miejskiego w Krakowie, nie sposób rozstrzygnąć ze względu na ograniczony zakres wpisów. Nie należy jednak tracić nadziei na odnalezienie ich kontynuacji, chociaż zadecydować może o tym chyba jedynie przypadek, zważywszy na brak jednoznacznych zapisek proweniencyjnych na inkunabule zawierającym dzieła Awicenny, a zapewne także na innych książkach należących do Macieja z Błonia. Kwerenda w wydanych katalogach inkunabułów i rękopisów nie przyniosła dotychczas niestety żadnych informacji na temat innych dzieł należących do tego lekarza, podobnych wpisów nie odnaleziono również w pozostałych drukach tego okresu przechowywanych w Bibliotece Prowincjalnej przy Wyższym Seminarium Duchownym Franciszkanów w Krakowie ${ }^{79}$. Nieznana zresztą pozostaje droga, jaką inkunabuł ten przebył, by ostatecznie trafić do tej książnicy, ani inne informacje o księgozbiorze Macieja z Błonia ${ }^{80}$. Niemniej wydaje się, że odnalezione zapiski, oprócz dostarczenia nowych danych do biogramu królewskiego lekarza, pokazują także, jak wiele jeszcze informacji biograficznych na temat mniej lub bardziej wybitnych postaci przełomu XV i XVI w. kryć mogą nadal biblioteki i, pośrednio, jak istotne jest położenie nacisku na katalogowanie zachowanych polskich zbiorów, zarówno poloników, jak i druków obcych.

${ }^{73}$ K. Sokołowska-Grzeszczyk, Znaki ksiązkowe lekarzy polskich, „Archiwum Historii Medycyny”, 44, 1981, nr 1, s. $20-21$.

74 Biogram zob. L. Hajdukiewicz, Maciej z Miechowa (Miechowita), w: PSB, t. 19, s. 28-33.

${ }^{75}$ M. Zdanek, Uniwersytet Krakowski wobec własnej przeszłości w XV i na poczatku XVI wieku. Stan i perspektywy badań, w: Felix indiget amicis. Studia z dziejów kultury duchowej i intelektualnej średniowiecza ofiarowane Profesorowi Krzysztofowi Ożogowi, red. W. Świeboda, M. Zdanek, Kraków 2016, s. 351-353.

76 Tamże, s. 352.

77 Tamże, s. 354-355.

${ }^{78}$ L.A. Birkenmajer, Zapiski historyczne wśród starych almanachów Biblioteki Jagiellońskiej, Kwart. Hist., 17, 1903, s. 405-421.

79 Zabytkowy księgozbiór został zdigitalizowany; zob. http://franciszkanska.pl/digitalizacja-zabytkowego-ksiegozbioru/ [dostęp: 16.08.2017].

${ }^{80}$ Informacji na ten temat nie wymieniają opracowania Jana Lachsa, np. Krakowskie księgozbiory lekarskie z XVI wieku, Kraków 1913; Kronika lekarzy krakowskich do końca XVI wieku. Przyczynki archiwalne, Kraków 1909; Lekarze krakowskiej kapituly katedralnej, Kraków 1905. 


\section{Aneks \\ Zapiski biograficzno-historyczne na wyklejce inkunabułu Inc.35.II z Biblioteki Prowincjalnej przy Wyższym Seminarium Duchownym Franciszkanów w Krakowie ${ }^{81}$}

[k. Ir]

bellum in Slesia pro festo sancti Michaelis ${ }^{82}$ fuit anno domini $1474^{83}$

$[\mathrm{k} . \mathrm{Iv}]^{84}$

[...] in octava Pasce ${ }^{85}$ de Warschowia in Cracoviam [...sa recessi] anno domini 1488 et eo tempore dux Boleslaus ${ }^{86}$ mortuus est ${ }^{87}$

Ad $|-\ldots .$.$| gradum acolitatus |-1484-|$

ad baccalaureatum in 1490 ad cinerum $^{88}$

[bellum] ad Slesiam fuit circa festum Michaelis ${ }^{89} 1474^{90}$

[p]estis magna [in] Mazovia fuit 1466 hoc anno

[na]tus germanus meus Georgius

[...] dux Janusius ${ }^{91}$ Mazovie feria secunda post Juliane mortuus

anno domini $1495^{92}$

Item natus $|-\ldots-|$ sum anno domini 1465

Item ad scolam datus sum [14] 1471

Item plebanus |-Simon-| Alexius est institutus ad ecclesiam parochialem in Kaszky ${ }^{93} 1473$ in die sancte Scolastice $^{94}$

Item in Julio accolitatus sum 1484

Item ex Warszovia Cracoviam studii causa in octawa Pasce ivi $1488^{95}$

Item Boleslaus dux eodem tempore mortuus est ${ }^{96}$

${ }^{81}$ W edycji not zastosowano wskazówki zaczerpnięte z Projektu instrukcji wydawniczej autorstwa Adama Wolffa (St. Źródł., 1, 1957, s. 155-181), ale rozwiązania dat zostały przeniesione do przypisów, zrezygnowano też z podziału na przypisy tekstowe i rzeczowe. Wszystkie skróty zostały rozwinięte bez ich zaznaczania, zachowano oryginalną ortografię, nie zachowano jednak układu tekstu, poprzestając na oddzielaniu akapitem poszczególnych zapisek. Za sprawdzenie poprawności odczytu serdecznie dziękuję mgr Urszuli Zacharze-Związek (IH PAN/IH UW).

${ }^{82}$ Tj. 29 września.

${ }^{83}$ Kazimierz Jagiellończyk miał wyruszyć z wyprawą na Śląsk 26 IX 1474; zob. Jana Długosza Roczniki czyli Kroniki sławnego Królestwa Polskiego, ks. 12: 1462-1480, red. K. Baczkowski i in., Warszawa 2009, s. 352.

${ }^{84} \mathrm{~W}$ poprzek lewego marginesu widnieją nieczytelne fragmenty noty.

${ }^{85}$ W 1488 r. okres ten przypadał na 6-15 kwietnia.

${ }^{86}$ Bolesław V (1450/1453-1488), syn Bolesława IV, książę mazowiecki, warszawski, nurski (1471-1488), zakroczymski (1471-1484); zob. J. Grabowski, Dynastia Piastów mazowieckich. Studia nad dziejami politycznymi Mazowsza, intytulacja i genealogia książąt, Kraków 2012, s. 617.

87 Bolesław V zmarł 27 IV 1488; zob. tamże, s. 488

${ }^{88}$ W 1490 r. Popielec przypadał 24 lutego.

89 Zob. przyp. 82.

90 Zob. przyp. 83.

91 Janusz II (1452/1454-1495), syn Bolesława IV, książę mazowiecki, ciechanowski, makowsko-różański, łomżyński (1471-1495), płocki, wiski, zawkrzeński (1475-1495), warszawski (maj-lipiec 1488), wyszogrodzki (1488-1495); zob. J. Grabowski, Dynastia Piastów mazowieckich, s. 617.

92 Maciej z Miechowa określił datę śmierci Janusza II na 23 lutego, w literaturze przyjmuje się jednak, że zmarł on 16 lutego, a 23 tm. został pochowany w Płocku; zob. tamże, s. 493. Podane przez autora wspomnienie św. Julianny przypadało właśnie 16 lutego, natomiast w 1495 r. był to poniedziałek, datacja wydaje się więc nie do końca poprawna, lecz wskazująca chyba na 16 lutego.

93 Zob. przyp. 29.

${ }_{94} \mathrm{Tj} .10$ października.

95 Zob. przyp. 85.

96 Zob. przyp. 86. 
Item in baccalarium promotus sum ad cineres $1490^{97}$ et eodem tempore Gysyczky ${ }^{98}$ Warkam et multas villas duci Conrado ${ }^{99}$ depredavit

Item ad Germaniam cum pueris ivi in mense Junio 1495

Item pueri mortui sunt circa festum $<$ Simonis Jude $>$ Michaelis 1497

Item ad studium doctoratus de Cracovia Italiam versus ivi in crastino Crispinis alias feria sexta ante Simonis hora XXIIa die 25 octobris $1498^{100}$

Item ex Italia doctor Cracovie veni primo die Augusti 1502

Item cardinalis Fredericus ${ }^{101}$ archiepiscopus Gnesnensis mense Marcio est mortuus $1503^{102}$

Item dux Conradus ${ }^{103}$ Simonis et Jude mortuus est eodem $1503^{104}$

Item dominus Johannes Lassky ${ }^{105}$ in Lublyn in vigilia sancte Katerine cancellarius factus est eodem ${ }^{106}$ Item Allexander ${ }^{107}$ rex in regem coronatus est 29 die Octobris $1501^{108}$

Item Johannes Albertus ${ }^{109}$ |-in regem-| mortuus est die 17 Junii $1501^{110}$

Item rex Allexander ${ }^{111}$ die 19 Augusti hora noctis tercia mortuus est $1506^{112}$

[k. II]

Allexander sextus ${ }^{113}$ papa coronatus est 27 Augusti [1492] ${ }^{114}$

\section{On royal physician Maciej of Błonie and his biographical-historical notes}

Summary: The edition of Avicenna's works preserved in the Provincial Library at the Higher Theological Seminary of Franciscans in Krakow contains interesting, handwritten biographical notes. It can be said with a high degree of certainty that they were written by Maciej of Błonie, a physician to Kings Aleksander I Jagiellon and Sigismund I the Old. This is suggested by the dates of his studies at the University of Krakow, the subject matter

97 Zob. przyp. 88.

98 Jan Giżycki, h. Gozdawa, tenutariusz w Wielkiej Woli; zob. K. Pacuski, Możnowładztwo i rycerstwo ziemi gostynińskiej, s. 99.

${ }^{99}$ Konrad III Rudy (1447/1448-1503), syn Bolesława IV, książę mazowiecki, płocki (1462-1471), czerski i liwski (1471-1503); zakroczymski (1484-1503); wyszogrodzki (1474-1488), warszawski (lipiec 1488-1503), makowsko-różański (1495-1503); zob. J. Grabowski, Dynastia Piastów mazowieckich, s. 617.

${ }^{100}$ Sformułowanie to wskazuje na trzy różne daty: in crastino Crispinis $=26$ października, feria sexta ante Simonis $=$ 27 i 25 października.

${ }^{101}$ Fryderyk Jagiellończyk (1468-1503), syn Kazimierza Jagiellończyka i Elżbiety Habsburżanki, biskup krakowski (1488-1503), kardynał-prymas i arcybiskup gnieźnieński (1493-1503); zob. H. Rybus, Fryderyk Jagiellończyk, w: PSB, t. 7, Wrocław 1958, s. $167-168$.

${ }^{102}$ Fryderyk Jagiellończyk zmarł 14 III 1503; zob. tamże, s. 169.

103 Zob. przyp. 99.

104 Wspomnienie Szymona i Judy przypada 28 października, Konrad III zmarł właśnie w tym dniu; zob. J. Grabowski, Dynastia Piastów mazowieckich, s. 479.

105 Jan Łaski h. Korab (1456-1531), kanclerz wielki koronny (1503-1510), arcybiskup gnieźnieński i prymas Polski (1510-1531); zob. P. Dembiński, Poznańska kapituł katedralna schyłku wieków średnich. Studium prozopograficzne 1428-1500, Poznań 2012, s. 449-452.

106 Wspomnienie św. Katarzyny przypada 25 listopada, co oznaczałoby, że Jan Łaski otrzymał tę godność 24 listopada. Faktycznie został on wybrany na urząd kanclerza 20 listopada, natomiast 24 tm. otrzymał pieczęć kanclerską; zob. P. Tafiłowski, Jan Easki, s. 37.

107 Aleksander Jagiellończyk (1461-1506), syn Kazimierza Jagiellończyka i Elżbiety Habsburżanki, wielki książę litewski (1492-1506) i król Polski (1501-1506); zob. F. Papée, Aleksander Jagiellończyk, w: PSB, t. 1, s. 58-61.

108 Aleksander Jagiellończyk został wybrany na króla 25 X 1501, a koronowany 12 XII 1501; zob. tamże, s. 59.

109 Jan Olbracht (1459-1501), syn Kazimierza Jagiellończyka i Elżbiety Habsburżanki, król Polski (1492-1501); zob. J. Garbacik, Jan I Olbracht, w: PSB, t. 10, s. 405-409.

${ }^{110}$ Data ta zgadza się z ustaleniami literatury; zob. tamże, s. 409.

111 Zob. przyp. 107.

112 Była to faktyczna data śmierci Aleksandra Jagiellończyka; zob. F. Papée, Aleksander Jagiellończyk, s. 60.

113 Aleksander VI (właśc. Rodrigo Borgia) (1431-1503), papież (1492-1503); zob. J.N.D. Kelly, Encyklopedia papieży, tłum. i uzup. T. Szafrański, Warszawa 1997, s. 352-355.

114 Faktycznie Aleksander VI został koronowany 26 VII 1492; zob. L. Pastor, Storia dei papi dalla fine del Medio Evo, t. 3 , Roma 1959, s. 341. 
of the notes, often devoted to Mazovia, his native region, and the content of the book itself. The discovered notes, spanning the period to 1506 , make it possible to fill the gaps and details of our knowledge about Maciej's early life - there is, among other things, the exact year of his birth given, the name and date of birth of his brother, the beginning year of his school education, the year he took holy orders of acolyte, and the years he went to Italy to study and came back to Poland after having obtained a PhD degree.

The article attempts to examine a possible milieu of Maciej, contacts he established which could have influenced his career, especially students of Krakow University, who studied at the same time, people who lived in Italy during the same period as Maciej; there is also a question asked about his contacts with Jan Łaski.

Attention was also paid to the nature of Maciej's notes - they appear to be draft records, without a chronological order, with numerous cross-outs and insertions. Only seldom did he put down a daily date, and he used various ways to date events. All this invites a question about the place of these notes among other diaries of the period. The article is annexed by the edition of biographical-historical notes of the royal physician.

Nota o Autorze: Ewa Kobylińska, dr, zatrudniona na stanowisku asystenta w Pracowni Historii Bibliotek i Czytelnictwa Biblioteki Narodowej, gdzie prowadzi badania nad księgozbiorami i czytelnictwem w Polsce późnośredniowiecznej.

Author: Ewa Kobylińska, PhD, employed as assistant at the Department of History of Libraries and Reading of the National Library, where she conducts research into book collections and reading in late-medieval Poland.

Pracownia Historii Bibliotek i Czytelnictwa

Instytut Książki i Czytelnictwa

Biblioteka Narodowa

al. Niepodległości 213

02-086 Warszawa

e-mail: e.kobylinska@bn.org.pl

\section{Bibliografia}

\section{Źródła}

Awicenna, Canon; De viribus cordis, Venezia 1490, Biblioteka Prowincjalna przy Wyższym Seminarium Duchownym Franciszkanów w Krakowie, sygn. Inc.35.II, <polona.pl/item/46955013/4/> [dostęp: 4.07.2017]

Księga promocji Wydziału Sztuk Uniwersytetu Krakowskiego z XV wieku, wyd. A. Gąsiorowski, współpr. T. Jurek, I. Skierska, W. Swoboda, Kraków 2000

Metryka Uniwersytetu Krakowskiego z lat 1400-1508, t. 1, wyd. A. Gąsiorowski, T. Jurek, I. Skierska, współpr. R. Grzesik, Kraków 2004

\section{Opracowania}

Birkenmajer L.A., Zapiski historyczne wśród starych almanachów Biblioteki Jagiellonskiej, Kwart. Hist., 16, 1902 , s. $445-457$

Birkenmajer L.A., Zapiski historyczne wśród starych almanachów Biblioteki Jagiellońskiej, Kwart. Hist., 17, 1903, s. 405-421

Czekajewska-Jędrusik A., Elementy rękopiśmienne w ksiażce drukowanej, w: Książka rękopiśmienna XV-XVII w., red. B. Bieńkowska, Z Badań nad Polskimi Księgozbiorami Historycznymi, t. 4, Warszawa 1980, s. 69-90

Korytkowski J., Prałaci i kanonicy katedry metropolitarnej gnieźnieńskiej od roku 1000 aż do dni naszych podtug źródet archiwalnych, t. 1, Gniezno 1883

Markowski M., Pierwsi doktorzy medycyny Uniwersytetu Krakowskiego w świetle źródet rękopiśmiennych, „Przegląd Tomistyczny", 6/7, 1997, s. 315-347

Pociecha W., Królowa Bona (1494-1557): czasy i ludzie Odrodzenia, t. 2, Poznań 1950

Skibniewska J., Dwór królewski Aleksandra Jagiellończyka w latach 1501-1506, Lublin 2015

Starzyński M., Ultima voluntas Alexandri Regis, w: Ecclesia, regnum, fontes. Studia z dziejów średniowiecza, red. S. Gawlas i in., Warszawa 2014, s. 258-267

Tafiłowski P., Jan Laski (1456-1531), kanclerz koronny i prymas Polski, Warszawa 2007 
Wiesiołowski J., Diariusz studencki burmistrza Goskiego, „Kronika Miasta Poznania”, 1, 1999, s. 67-77

Wiesiołowski J., Pamiętnik starosty Pampowskiego, „Kronika Miasta Poznania”, 4, 2004, s. 120-132

Wójcik R., Autobiographical Marginal Notes in Early Printed Calendars, Almanacs and Ephemerides as the

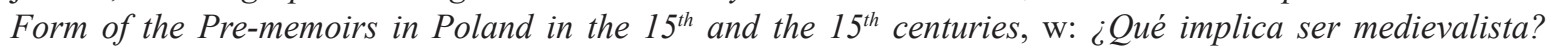
Prácticas y reflexiones en torno al oficio del historiador, t. 3, red. A.V. Neyra, G. Rodríguez, Mar del Plata 2012, s. 163-197, >repozytorium.amu.edu.pl/bitstream/10593/6000/1/Diaries_Rafa\%C5\%82\%20W\%C3\%B3jcik.pdf> [dostęp: 29.08.2017]

Wójcik R., Zapiski z efemeryd i almanachów XV i XVI wieku. Plan wydawniczy serii „Diariusze Staropolskie”, w: Kalendarze staropolskie, red. I. Dacka-Górzyńska, J. Partyka, Warszawa 2013, s. 53-60

Zdanek M., Uniwersytet Krakowski wobec własnej przeszłości w XV i na początku XVI wieku. Stan i perspektywy badań, w: Felix indiget amicis. Studia z dziejów kultury duchowej i intelektualnej średniowiecza ofiarowane Profesorowi Krzysztofowi Ożogowi, red. W. Świeboda, M. Zdanek, Kraków 2016, s. 319-359 